\title{
Studies on seafood production systems in the South-west Region of Bangladesh
}

\author{
M. R. Islam ${ }^{1 *}$, M. M. Haque ${ }^{2}$ and M. M. Rahman ${ }^{2}$ \\ ${ }^{1}$ Department of Aquaculture, Bangabandhu Sheikh Mujibur Rahman Agricultural University, Gazipur and ${ }^{2}$ Department \\ of Aquaculture, Bangladesh Agricultural University, Mymensingh-2202, Bangladesh \\ E-mail: rabiul.islam@bsmrau.edu.bd
}

\begin{abstract}
The present study was conducted to understand existing production system of shrimp and prawn (seafood) with gher ${ }^{1}$ farming in the south-western region of Bangladesh from January to March 2014. Three gher farming clusters in three Upazilas of Bagerhat district were selected to carry out this study to assess the fact above using focus group discussion, key informant interview, questionnaire survey, physical observation, and literature review. The study revealed that gher farming system has changed the cropping patterns dramatically. This diversified farming system produces prawn, carp fish, boro paddy, and vegetable in the field where only single crop of paddy was cultivated. Gher dikes were used to produce vegetables, fruits and the central part for rice cultivation. Whereas the whole water body (during monsoon) and canals (during dry season) were used to culture finfish and prawn. Farmers were mainly found to use commercial feed with a rare amount of homemade feed because of the availability of commercial feed. Most of their investment goes for buying feed, PL and were found to take loan with high interest from banks or depot owners. Decreased salinity due to siltation in Mongla river resulted in increased overall production. The evidence presented in the study confirms that gher farming system impacting positively in the south-west region of Bangladesh.
\end{abstract}

Keyword: Seafood, Gher, Prawn, Shrimp, South-west region of Bangladesh

\section{Introduction}

Seafood is the commercial term used internationally to denote all the aquatic products including culture and captured finfish, shellfish and other aquatic edible animals and plants. Shrimp and prawn as seafood are mainly cultured in the south-western part of Bangladesh. Shrimp and prawn culture is very popular in south-western region of Bangladesh because of its market demand and suitability to culture with other commercially important species. Presently commercial shrimp farming has taken place in Khulna, Bagerhat, Shatkhira, and Patuakhali District. Prawn culture has been spread extensively at Mollahat, Fakirhat, Chitalmari, Bagerhat Sadar and Kachua Upazilla of Bagerhat district. Thousands of farmers have converted their paddy fields to farms locally called ghers to accommodate a profitable shrimp culture practice (William, 2003).

Gher farming is an integrated prawn-fish-rice joint culture, which is practiced widely in south-west region of Bangladesh. It is an efficient and diversified farming system that produces a staple food crop (rice and fish) in conjunction with a high value cash crop (prawn) and provides a range of social, environmental and economic benefits. Shrimp and prawn have a great role in the economy of Bangladesh. Bangladesh is earning a lot of foreign exchange by exporting them. This trend has been increasing since 1995 while Bangladesh earned US\$313 million by exporting seafood, recently this figure increased to US\$450 million (BFFEA, 2010). According to the latest statistics, shrimp and prawn alone contributed $90 \%$ of seafood export earning by exporting 43,953 MT frozen shrimp and prawn (DoF, 2014). In 2010-11 financial year, by exporting of 84,905 MT shrimp and other fishery products, the country earned US\$ 534 million in which shrimp alone contributed $70 \%$ of the total export in spite of severe price fluctuations in the international market. There is a noticeable increase in export value of shrimp particularly in USA and European countries. Paddy and vegetables are sold in the local and domestic market. Under this situation, this was the main interest of the present study to understand existing farming system of shrimp and prawn.

\footnotetext{
${ }^{1}$ Gher is a Bangladeshi local term used for modified rice fields or ponds located beside canals or rivers that are used to cultivate shrimp and finfish since early 1970s.
} 


\section{Materials and Methods}

\section{Description of the study area}

The study was conducted in three Upazilas of Bagerhat district of Bangladesh (Fig. 1). This study sites was considered because it is one of the most important shrimp and prawn farming areas of south-west region. There are nine Upazilas in Bagerhat district. Due to this importance, a number of government and donor funded research and development projects have been working since long in this region. The study was conducted in Badukhali under Bagerhat Sadar upazila, Kumarkhali under Fakirhat upazila, and Alipur under Kachua upazila (Fig. 2). All of these three villages are about 1 hour drive from Bagerhat Sadar.

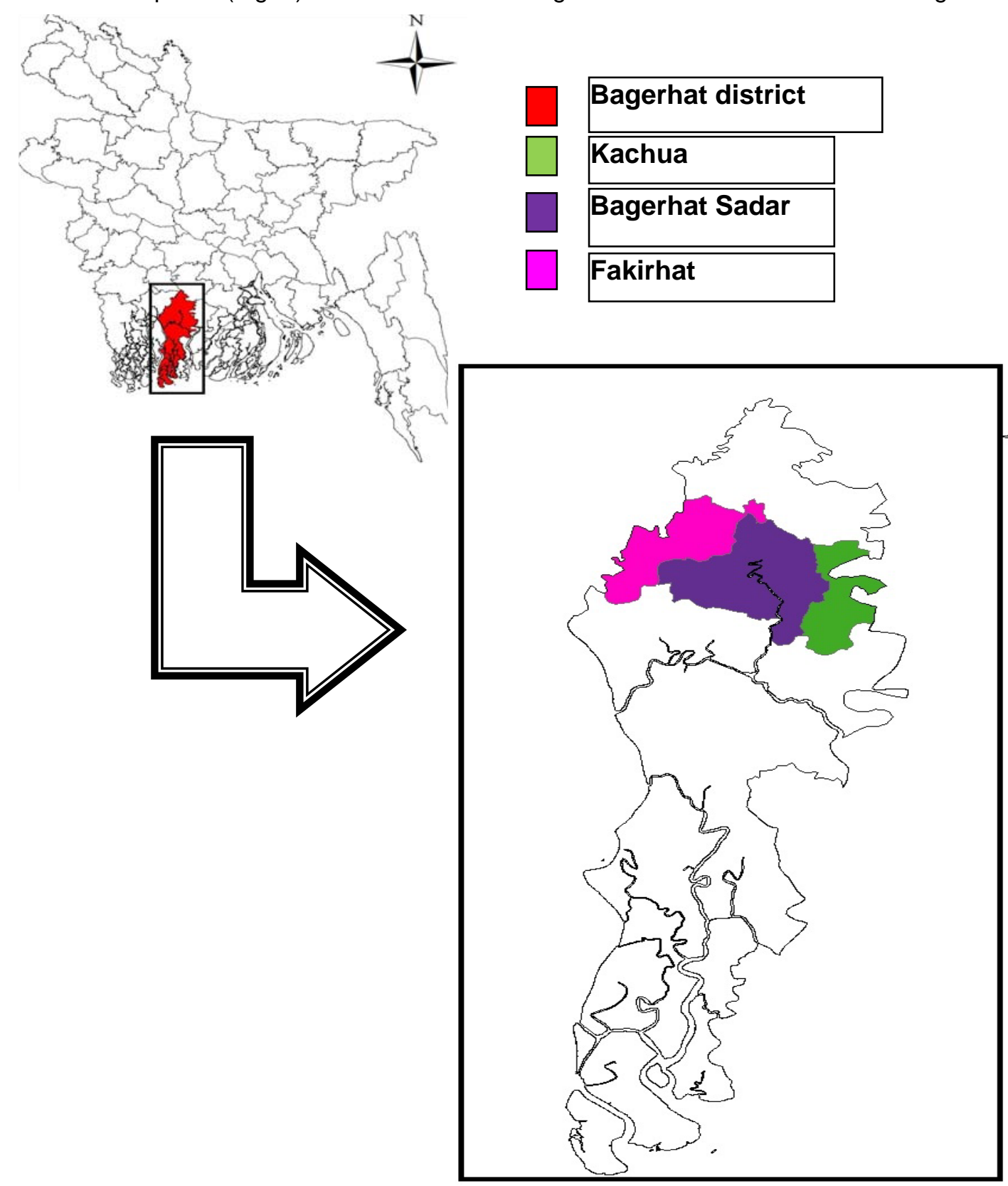

Fig. 1. Map of Bangladesh showing the position of Bagerhat district. 

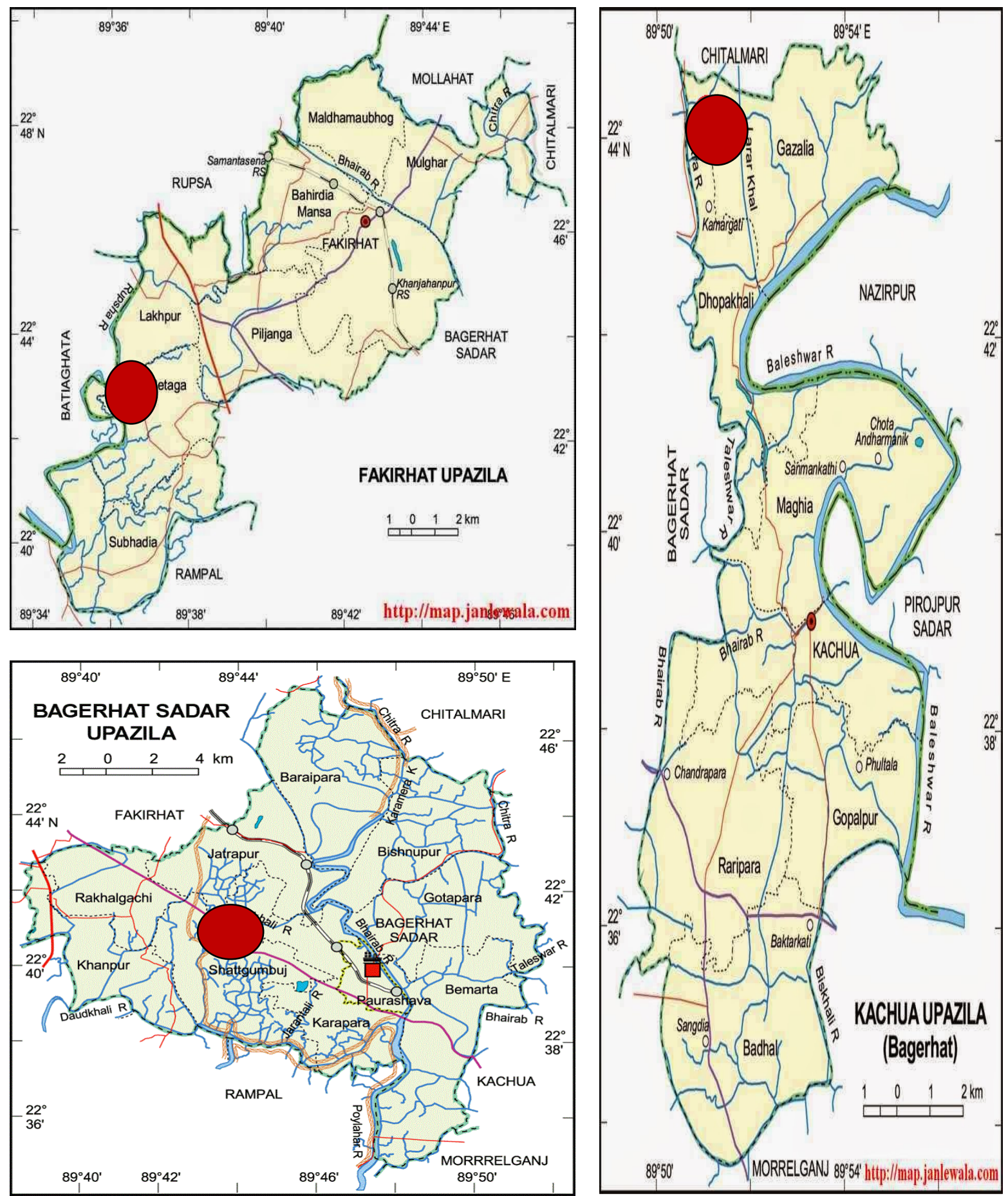

Fig. 2. Map of Fakirhat, Kachua and Bagerhat Sadar upazila showing the study area 


\section{Community selection}

Community selection was done under the following criteria (Table 1). The areas were well accessed to do the field work in terms of road communication, farmer participation and local support from Shrimp Research Station, Bagerhat which is a new station of Bangladesh Fisheries Research Institute (BFRI).

Table 1. Community selection criteria for the proposed study

\begin{tabular}{|c|c|c|c|}
\hline Community & Location & $\begin{array}{c}\text { GPS } \\
\text { coordinates }\end{array}$ & Farming type \\
\hline Alipur & $\begin{array}{l}\text { Kachua } \\
\text { upazila }\end{array}$ & $\begin{array}{l}22.746223^{\circ} \mathrm{N} \\
89.842974^{\circ} \mathrm{E}\end{array}$ & $\begin{array}{l}\text { Bagda, golda and carp polyculture } \\
\text { Dike cropping for horticulture } \\
\text { Rice production during boro }\end{array}$ \\
\hline Kumarkali & $\begin{array}{l}\text { Fakirhat } \\
\text { upazila, }\end{array}$ & $\begin{array}{l}22.6856^{\circ} \mathrm{N} \\
89.5959^{\circ} \mathrm{E}\end{array}$ & $\begin{array}{l}\text { Golda and carps polyculture } \\
\text { Dike cropping for horticulture } \\
\text { Rice production during boro } \\
\text { Low land and, freshwater logging, lack saline } \\
\text { water, poor scope of bagda culture and poor } \\
\text { productivity }\end{array}$ \\
\hline Badukhali & $\begin{array}{l}\text { Bagerhat } \\
\text { Sadar } \\
\text { upazila }\end{array}$ & $\begin{array}{l}22.697971^{\circ} \mathrm{N} \\
89.746896^{\circ} \mathrm{E}\end{array}$ & $\begin{array}{l}\text { Bagda, golda and carp polyculture } \\
\text { Dike cropping for horticulture } \\
\text { Rice production during boro }\end{array}$ \\
\hline
\end{tabular}

\section{Cluster selection}

Cluster selection was done by using Google Earth software (Fig. 3). A cluster of about 50 ghers from all of these 3 villages were selected for the study. Historical photos of the same cluster of ghers were also taken by using the same software to compare the physical changes with time. From the cluster, the ghers were individually numbered and the owners were identified. Then detail investigation was done to assess the change over the last 10 years.

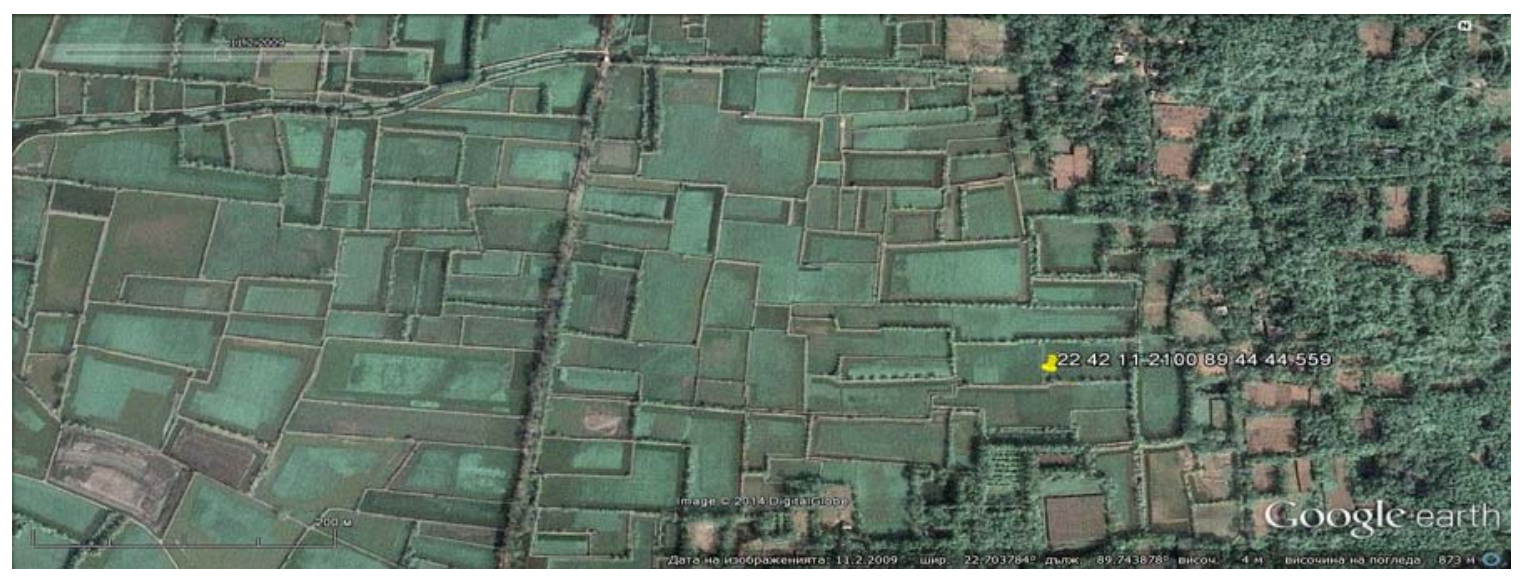

Fig. 3. Cluster selection by using Google Earth image.

\section{Data collection}

Data were collected by focus group discussion, key informant interview $(n=6)$, questionnaire survey (40), physical observation and literature review. The collected data were also crosschecked by people of local NGOs working in the area and government officials. Data related to gher size, type of ownership, change of ownership were collected. Shrimp and prawn farming household well-being ranking was carried out in the time-scale of 10 years before and after with the participation of key informants. 


\section{Primary data source}

The primary data were assembled through field survey at the village level by using a structured questionnaire (Fig. 4). The data were collected by both physical observation and interview with gher farmers at household, field and market level.

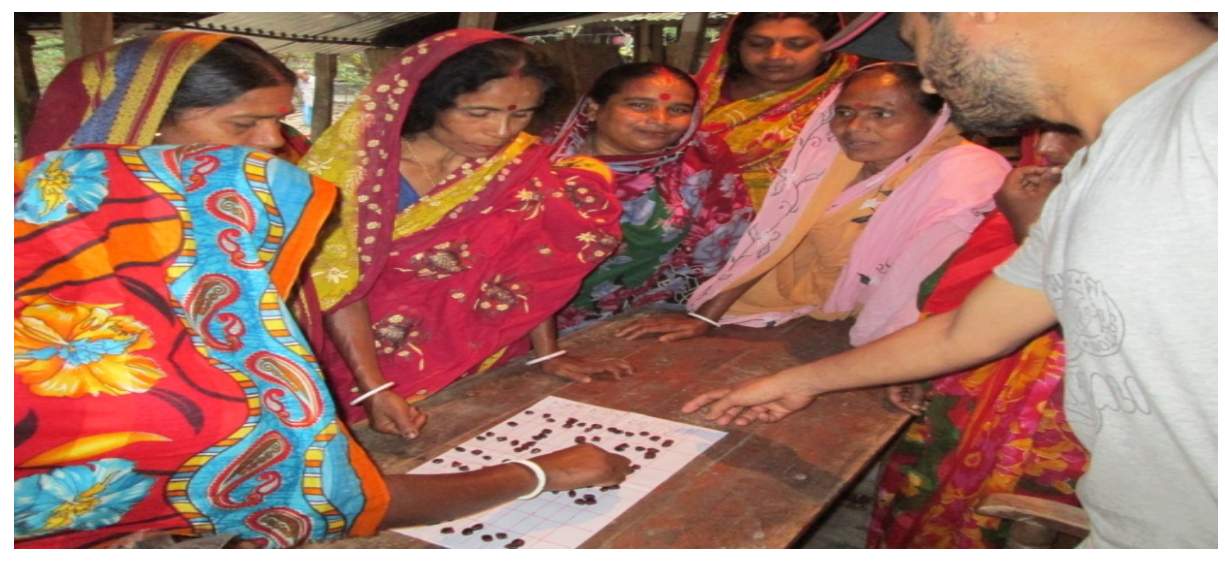

Fig. 4. Female family members of the respondent farmers contributed to the data collection

\section{Secondary data source}

Further relevant information were collected from books, thesis papers, journals, government officials like district and upazila fisheries officers, school teachers, local leaders like Union Parishad member and chairman, doctors of union health complex, and local surveyors for land related information.

\section{Data analysis}

Collected information obtained from the survey was accumulated, grouped and interpreted according to the objective. They were entered into MS Excel spreadsheet and analyzed following the requirements of the objectives.

\section{Results}

\section{Gher farming system}

Gher farming can be considered as a method of combining Aquaculture and Agriculture on one plot. During the rainy season the whole water body is used for cultivation of shrimp and fish. However, when the weather is dry then the canals are used for shrimp and fish and rice is planted in the central plot (Fig. 5). The dikes are used for growing vegetables and fruits throughout the year. Main crops in integrated gher farming system are prawn/shrimp, paddy, vegetables, finfish, and trees.

\section{Dike cropping}

Gher dikes were used for producing vegetables and fruits. Carrot, tomato, potato, radish, ash gourd, pumpkin, cucumber, ladies finger, spinach, brinjal, bean, cabbage, cauliflower, chili, onion, bitter gourds were mostly cultured species. Average production of vegetables was about $19,930 \mathrm{~kg} / \mathrm{ha} / \mathrm{year}$. Farmers confirmed that about $10 \%$ of their income derived from vegetables and sometime they get back their investment by selling only vegetables. Dike cropping was found more popular among small gher farmers than the large, because large gher farmers have to concentrate more on fish and prawn. Besides meeting family demand, they sell vegetable on local and domestic market. Fruits like banana, plum, papaya, coconut and guava were also produced in gher dike. In some ghers, there were also date trees on the dike and they collect date juice from them. 


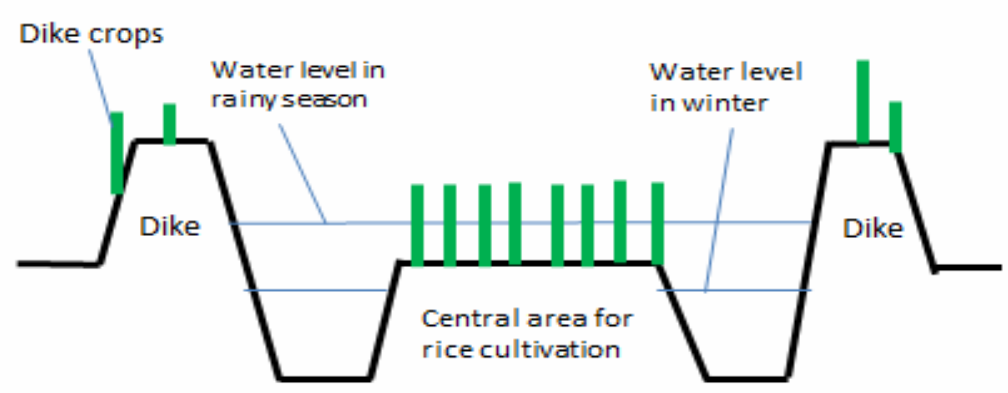

Fig. 5. Diagram of rice-prawn gher farming system.

\section{Rice cultivation}

The central part of gher was used for rice cultivation. In the study area farmers produce boro rice during the dry season. As the study area was low laying, so it was not possible to produce amon rice during monsoon because of high water level in the gher. Production of rice was about 10,630 kg/ha/year.

\section{Finfish culture}

Different species of finfish locally called white fish were cultured with prawn. Rui (Labeo rohita), catla (Catla catla), mrigal (Cirrhinus cirrhosus), silver carp (Hypophthalmichthys molitrix), grass carp (Ctenopharyngodon idella), common carp (Cyprinus carpio), pangus (Pangasius hypophthalamus) were most cultured species (Fig. 6). Production of finfish was about $1329 \mathrm{~kg} / \mathrm{ha} / \mathrm{year}$. Production of finfish was found increasing due to decreasing salinity.

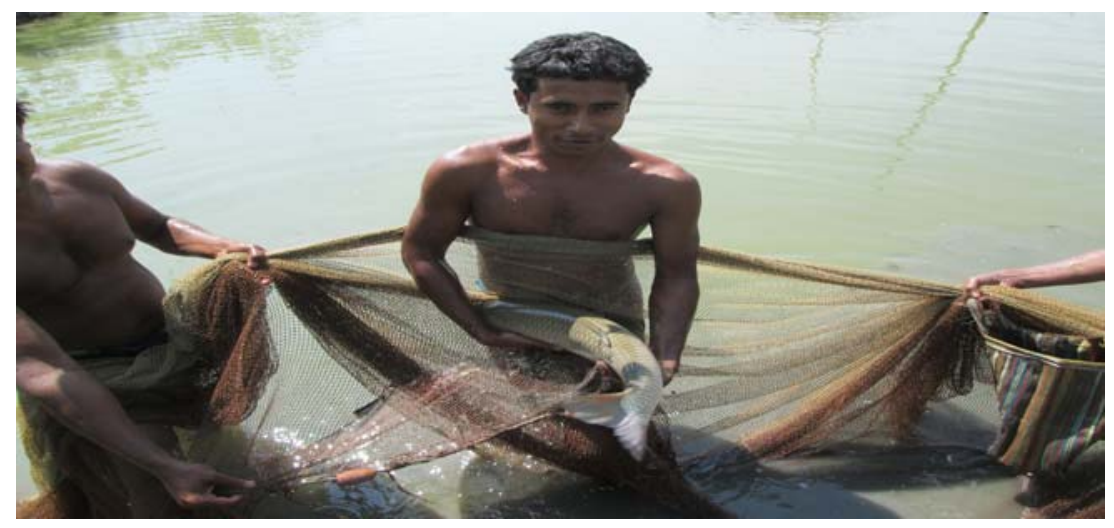

Fig. 6. Finfish locally called white fish culture with prawn.

\section{Prawn culture practice}

During Bengali Month Falgun-Choitro (mid February-mid April) farmers prepared their pond. Pond depth is not more than 1-2 miters. Pond preparation includes drying, dike repairing and liming (1 $\mathrm{kg} / \mathrm{decimal})$. After 4-5 days of liming, they watered the pond. As per farmers' perceptions light saline water is better but if not found then they used rain water or deep tube-well water.

During April-May farmer started releasing prawn PL. They collect PL from Mongla, one of the southern upazila (sub-district) of Khulna district. Most of the farmers preferred wild PL than the hatchery PL. Survival rate and growth rate was high in wild PL as farmers reported. Farmers informed that PL collected in Bengali month Boishakh (mid April-mid May) from wild source in river is the best because after Boishakh the collected PL get dominated by female which is not desirable by the farmers. Stocking density was $14,300-21,500 \mathrm{PL} / \mathrm{ha}$ and it also depends on their ability to buy PL. If they are able to, they stock more PL due to the risk of mortality. If most of the PL survive they sell or stock excess PL to another gher. 
Farmer separates male and female prawn after 4 month of stocking in term of the presence of gonad in male prawns (Fig. 7). The growth of male prawn was found higher and monosex culture was reported to give good production. Production of male was about $714 \mathrm{~kg} / \mathrm{ha}$ and female was about $360 \mathrm{~kg} / \mathrm{ha}$.
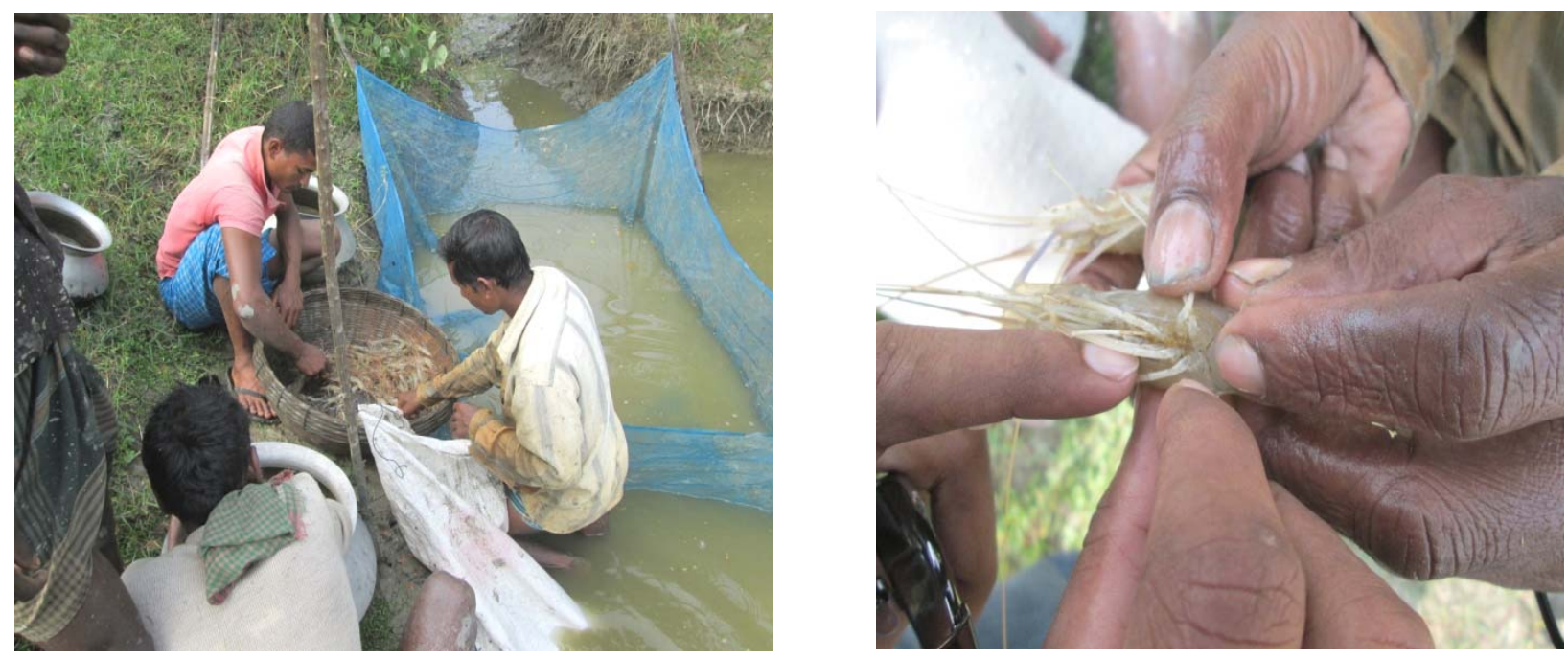

Fig. 7. Separation of male and female prawn by the farmers

During December-February after a period of 9 to 10 month rearing, when most of the prawn attained the weight of $80-100 \mathrm{~g}$ they harvest them by using seine net or cast net. Water level at that time remains lower so harvesting became easier. Farmers sold their prawn in the local depot.

Farmers released shrimp PL in Falgun (mid February-mid March) and harvested after 3 month of rearing. They continued releasing and harvesting at an interval of three month. In Alipur of Kochua upazila, they cultured both shrimp and prawn in the same pond. Farmers collected hatchery produced shrimp PL via local agents originated from Cox`s Bazar.

\section{Feeding practice}

Farmers were found to use mainly commercial feed. They also used rice bran, wheat bran, egg yolk, boiled rice and wheat, mustard oil cake, flower, etc. The use of homemade feed was very rare because of the availability of commercial feed. Moreover preparation of homemade feed is time consuming and price of input was reported increasing. After releasing fry, they used fine food like flower, rice bran for a period of 15 days. After 15 days they used fish meal. Three month after stocking they started using snail (Pila globosa) meat. Farmers believe that snail meat is the best for higher growth rate. However, the use of snail meat is decreasing due to unavailability of snail in the market. Over harvesting from natural sources is responsible for the scarcity of snail meat. In 1998, the amount of snail meat trade in Bagerhat was $164,192,250 \mathrm{~kg}$ and value at BDT 600 million (Alam and Demaine 2004). Mainly women were found involved in the work of breaking snail shell. Snail meats are used in the gher and shells are used in producing lime. Before a month of harvesting, farmers use boiled wheat. They believe that it increases weight of prawn.

\section{Fertilization}

Farmers used different type of fertilizers. They were found mostly using cowdung, urea, and triple upper phosphate (TSP). A few of them believed that cow dung was responsible for virus attack and they avoided that. They used fertilizer for growing natural food. Farmers regularly used lime in the pond at a rate of $1 \mathrm{~kg} / \mathrm{decimal}$ for controlling water quality. For increasing dissolved oxygen they used chemical (e.g. Quick Oxygen) or by netting, pumping water and creating agitation by hitting water with a bamboo stick. There was no use of herbal pesticide. 


\section{Farming investment and household income}

Farmers were found indebted to take loan with a high interest from different NGOs or from banks or even from the depot owners in a condition to sell their prawn in that depot. There was no self-help group found in the study area from where they can take loan. They had to invest for pond preparation, fertilizer, postlarvae, feed, medicine, labor, transport. A large portion of the investment goes for buying commercial feed and PL. Return on investment mainly comes from prawn/shrimp. Farmers also earned from paddy, vegetable, and finfish production (Table 2).

Table 2. Distribution of investment and cost in a small gher

\begin{tabular}{llll}
\hline \multicolumn{2}{c}{ Investment (\%) } & \multicolumn{2}{c}{ Return (\%) } \\
\hline Pre-stocking gher preparation & $10 \%$ & Shrimp/prawn production & $50 \%$ \\
Stocking of PL & $40 \%$ & Paddy & $30 \%$ \\
Post-stocking inputs & $30 \%$ & Vegetables & $10 \%$ \\
Labor & $10 \%$ & Fin fish & $10 \%$ \\
Others & $10 \%$ & & \\
\hline
\end{tabular}

Although the main occupation of farmers in the study area was gher farming some people were also engaged in small business. A few people were doing job. They also had additional income from betel leaf culture, trees, dairy and poultry rearing. Those people who did not have any land, work as day laborer in others gher. Those people who did not have enough manpower to operate gher they leased out their land. In Badukhali and Alipur farmers leased out there land at a price of BDT. 71,430-85,700/ha/year maximum three years, but in Kumarkhali it was BDT. 42,900-57,200/ha/year. The difference was because Kumarkhali is low lying area and they cannot culture shrimp (bagda) as much as farmers of Badukhali and Alipur.

\section{Problems and potentials in gher farming}

Shrimp farmers faced some problems during farming such as high production cost, shrimp diseases, natural disaster, inadequate supply of snail, increasing price of feed. They got technical support from Department of Fisheries (DoF). They also got technical and financial support from different NGOs like Grameen Bank, TMSS, HID, Nobolok, ASHA, Manob Kollan. There were about 13 different NGOs working in Bagerhat District.

However, there was a potential of decreasing salinity day by day in the study area as reported by the local farmers. Last four years data on salinity of Doratana River collected from Upazila Fisheries Office, Bagerhat Sadar clearly shows the decline in salinity (Fig. 8). The reason of salinity reduction was siltation in Mongla River.

Saline water is transported by tidal action along Mongla river which, through the man-made navigation channel Katakhal, mixes with the less saline water from Gashiakhali river and is carried upstream to Doratana river. Doratana river supplies water to most of Bagerhat Sadar upazila. The decreased tidal inflow in Mongla river, confirmed also by farmers, results in mostly the less saline water from Baleshwar river being pushed upstream Doratana into Sadar upazila.

Gher farmers perceived that the salinity reduction is blessing for them. Due to the decreased salinity, production of rice was found increasing. Moreover, it is possible to grow finfish and farmers started producing finfish increasingly due to decreasing salinity of the water in the gher as well as the local river. Accordingly, their overall income for increased production of prawn/shrimp, rice and finfish was reported to be increased to a greater extent. 


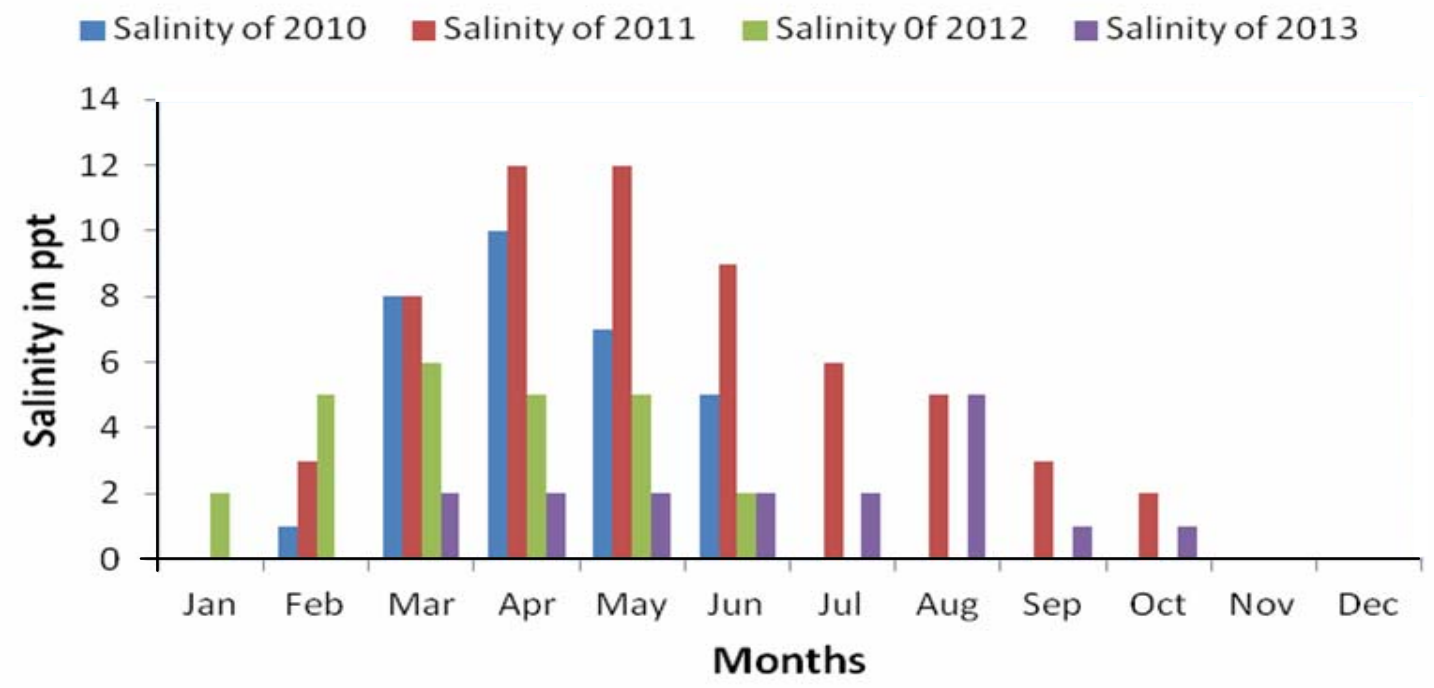

Fig. 8. The decreasing trend of salinity of Doratana river, Bagerhat in the study area

\section{Discussion}

Gher farming has been developed in an integrated system with various benefits locally. In integrated gher farming system, farmer produced fish and shrimp/prawn in addition with rice, vegetables and fruit trees. After harvesting prawn during December-January they grow boro rice for duration of January-April. Fruits and vegetables are produced on the dike round the year. The same observation was reported by (Barmon, 2004). After meeting family demand vegetables are sold in the domestic market. Farmers confirmed that dike cropping helps them to manage capital for investing in gher farming.

Stocking and post-stocking covers about $40 \%$ and $30 \%$ of the cost respectively. According to (Ahmed, 2010) variable cost, seed and feed dominates other cost with an average $39 \%$ and $33 \%$ of total cost, respectively. Stocking cost is mainly for seeds and post-stocking costs include fertilizers, lime, feed, transport, harvesting etc. In case of fertilizer, farmers were found mostly using cow dung, urea and TSP. According to (Ahmed, 2001) reported that annual fertilization rate was $1467 \mathrm{~kg} / \mathrm{ha}$ of cow dung, 403kg/ha of urea and $217 \mathrm{~kg} / \mathrm{ha}$ of TSP at varying frequency. Potential return of integrated gher farming comes from prawn, paddy, vegetables and finfish.

Gher farming has capacious impacts on the economic status of the farmers. There is a regular flow of income through gher farming. They can produce both rice and vegetable along with fish and shrimp. Moreover, it made possible to involve the female members of the family in gher farming. Women are also involved in feeding of prawns, dike cropping, farm supervision, prawn harvesting and post harvesting handling (Ahmed, 2010). Ahmed (2001) also reported that women are involved in the shell breaking activity at a rate of BDT 50/gunny bag of snail. In the present study it was found that all the farmers indicated that they were able to improve their socio-economic status after being involved in the gher farming. That is why gher farming is becoming very popular instead of rice cultivation in the south-west Bangladesh. Salinity of Kachua, Fakirhat and Bagerhat Sadar upazila was found decreasing. This decreasing trend of salinity had a positive impact on production. It was possible for them to produce more rice, vegetable and finfish. These above indicate that the gher farming has huge positive impacts on the income and food security of the local community. 


\section{Summery and conclusion}

Integrated gher farming system is blooming in the south-west region of Bangladesh very fast and the crops specially shrimps and prawns have consistently high value in the international market. Integrated gher farming system is becoming popular among farmers for its profitability than the traditional farming system. Farmers are getting various types of crop from their land at a time and there is continuity in earning round the year. This has a great positive impact on their socio-economic status of farming households. This integrated farming system has very high potential to be expanded in other part of Bangladesh meeting the demand of seafood from the international market.

\section{References}

Ahmed, N. 2001. A study on gher based freshwater prawn farming in Bangladesh. Bangladesh Journal of Fisheries Research 24: 13-19.

Ahmed, N., Elisson, E.H. and Muir, J.F. 2010. Rice field to prawn farms: A blue revolution to Bangladesh. Aquaculture International 18: 555-574.

Alam, R. and Demaine, H. 2004. Integrated prawn farming systems of south-east Bangladesh. GNAEP Working Paper, Greater Noakhali Aquaculture Extension Project (GNAEP), Noakhali, Bangladesh. pp. 8.

Barmon, B.K., Kondo, T. and Osanami, F. 2004. Labor demand for rice-prawn gher farming in Bangladesh: A case study of Khulna District. The Review of Agricultural Economics, 60: 273-287.

BFFEA. 2010. Annual report of Bangladesh Frozen Foods Exporters Associations Dhaka, BFFEA monthly newsletter, January. pp. 5.

DoF. 2014. Fisheries Statistical Yearbook of Bangladesh 2012-2013.Fisheries Resource Survey System. Department of Fisheries, Ministry of Fisheries and Livestock, The Government of the People's Republic of Bangladesh. pp. 52.

William, D. 2003. Small scale freshwater prawn culture boosts Bangladesh economy, household income. Global Aquaculture Advocate. pp. 45. 